\title{
An Extraordinary Wedding
}

Some Reflections on the Ethics and Aesthetics of Authorial Strategies in Ethnographic Filmmaking

Rosita Henry and Daniela Vávrová

\section{(2) OpenEdition}

\section{Journals}

Electronic version

URL: http://journals.openedition.org/anthrovision/2237

DOI: $10.4000 /$ anthrovision.2237

ISSN: 2198-6754

\section{Publisher}

VANEASA - Visual Anthropology Network of European Association of Social Anthropologists

Electronic reference

Rosita Henry and Daniela Vávrová, «An Extraordinary Wedding », Anthrovision [Online], 4.1 | 2016, Online since 14 February 2017, connection on 01 May 2019. URL : http://journals.openedition.org/ anthrovision/2237 ; DOI : 10.4000/anthrovision.2237

This text was automatically generated on 1 May 2019.

(C) Anthrovision 


\title{
An Extraordinary Wedding
}

Some Reflections on the Ethics and Aesthetics of Authorial Strategies in Ethnographic Filmmaking

\author{
Rosita Henry and Daniela Vávrová
}

1 Anthropologists and other scholars have long reflected upon the various authorial strategies employed in the construction of written ethnographic texts (Clifford and Marcus 1986; Geertz 1988). Similar questions of authorship and voice have been raised in relation to the making of ethnographic and documentary films (e.g. Ruby 1992; MacDougall 1998). Filmmakers frequently face intractable dilemmas of both ethics and aesthetics, when deciding what to include and what to sacrifice from hours of footage of complex socio-cultural practices and performances.

2 We too have grappled with these dilemmas in the making of An Extraordinary Wedding, a film about brideprice transactions in the Western Highlands of Papua New Guinea. In this paper we reflect upon the authorial strategies we have employed in this work-inprogress. We consider issues of authorship and authority and discuss our attempts to work with some of the 'characters' in the film to create an audio-visual narrative that can be understood and appreciated by a broader audience without diminishing the integrity of the lifeworld represented.

\section{An invitation}

3 In December 2012, one of the authors of this paper, Rosita Henry, was invited to Papua New Guinea to attend the brideprice exchange of the daughter of an old school friend from the Western Highlands. It was a poignant visit for her, as her friend, Magdaline (Maggie) Wilson, had passed away suddenly and unexpectedly three years earlier. Customarily, Maggie would have played a significant part in organizing the event, but her English husband Keith Wilson, and their children Bernadine, Olivia, Maki, and Nadia now had to shoulder the responsibility for working with their Highlands kin to arrange this complex ceremonial gift exchange between intermarrying clans and their allies. 
Maggie had regularly participated in, and contributed to, brideprice exchanges when she was alive but she had also spent much time thinking about the practice and was concerned about how brideprice exchanges had changed over time and whether they had become corrupted under conditions of modernity. She was proud of the traditions of her people but was worried about the transformations that were taking place and what this signified in terms of the status of women.

In the case of her own wedding to Keith Maggie had refused to allow her father and brothers of the Penambi Wia clan to ask for or accept brideprice, explaining to them that it was not a customary practice among Keith's people. Yet, now their youngest daughter Nadia and husband-to-be Hebrew Maipson, a Mogei Nambuga man, wanted to be married in the customary way of their Highlands kin, as well as by a priest. For the sake of Nadia, her father and her siblings agreed to the brideprice exchange going ahead.

\section{Nadia and Hebrew's Wedding}

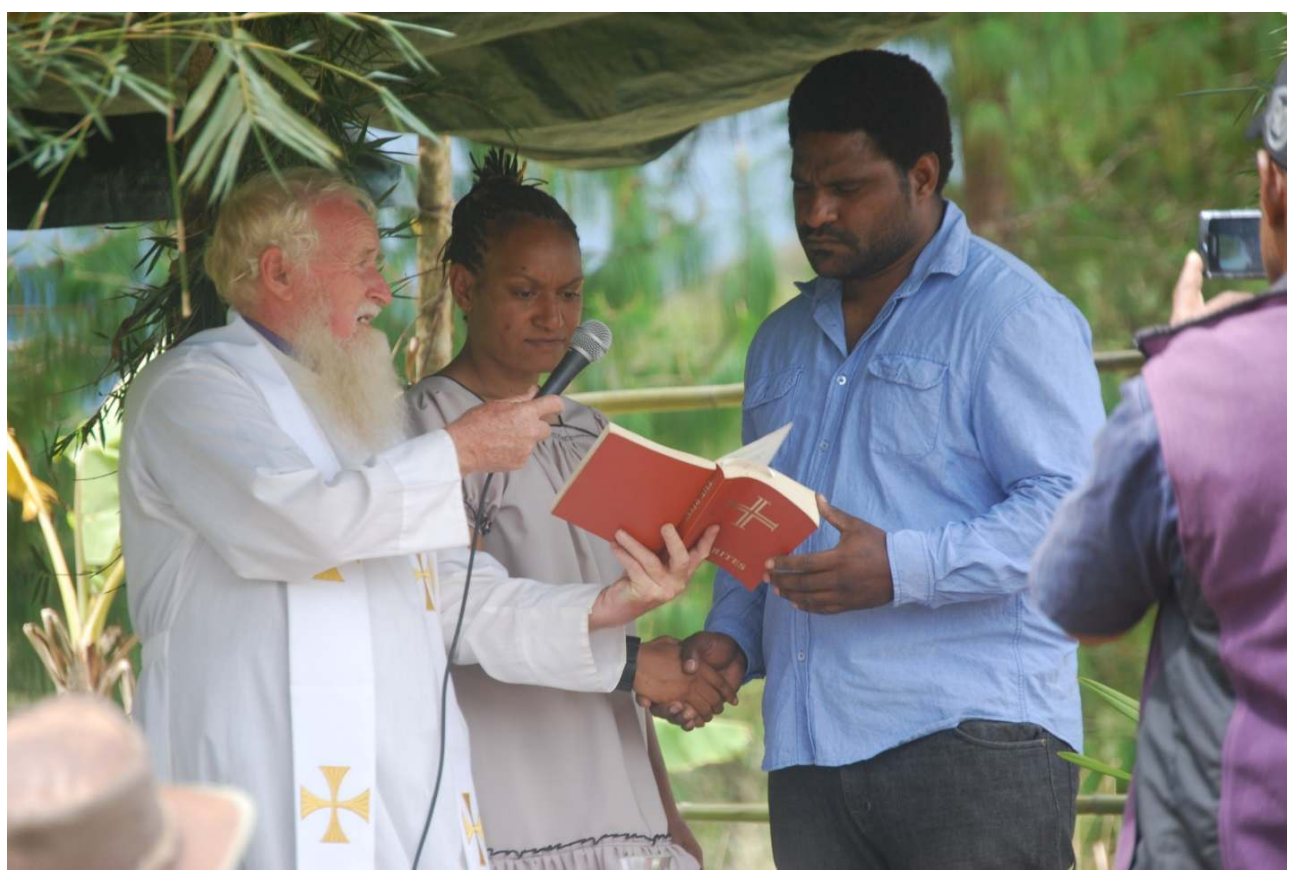

Father Garrett Roche conducting the marriage of Nadia and Hebrew 4 January 2013

PHOTO BY KANAWI DANOMIRA

Thus, as an old friend of the mother of the bride, Rosita found herself eagerly accepting an invitation to attend and record the main series of events that comprised Nadia's marriage transactions.

\section{Mother of the bride}

7 Maggie was born in the Western Highlands near Mt Hagen. She grew up in the village as the daughter of Kuan, a Penambi Wia man, but her biological father was Patrick Leahy, older brother of Michael and Daniel Leahy, who were among the first white men to explore the Highlands of PNG while on an expedition searching for gold.

8 Maggie and Rosita met at boarding school in Australia during the 1970s and kept in touch over the years closely following the unfolding of each other's adult lives, Maggie's in PNG, 
and Rosita's in Australia. Rosita visited Maggie in Mt Hagen in 1974 but it was not until the year 2000 after finally submitting her doctoral thesis in anthropology that she was able to return. She travelled to Mt Hagen to conduct research on the iconic films by Bob Connolly and Robin Anderson First Contact (1983), Joe Leahy's Neighbours (1989) and Black Harvest (1992), which feature members of Maggie's extended family and which Maggie had facilitated by providing advice and research assistance to the filmmakers (Connolly and Anderson 1987; Connolly 2005). In fact, Maggie appears in a scene in First Contact, eliciting narratives from a group of women about their memories of the Leahy brothers and other white men who first arrived in the Highlands in the 1930s.

9 After viewing these films and screening them for many years in undergraduate anthropology classes, Rosita had wondered what Ganiga people, Joe Leahy, and other members of the Leahy family, including Maggie, thought of the trilogy and the way their lives had been represented to a global audience through these films. Maggie happily facilitated the research project, providing accommodation and transport and her own son, Maki, as a research assistant and translator. Yet, it was not really a study Maggie would have chosen herself; she would rather have done research about something much closer to her heart - gender relations and the problems facing women in the Highlands, including domestic violence, poor health care, and tough childbirth conditions. She was particularly interested in the question of brideprice and its impact on the status and treatment of women.

10 After her funeral in 2009 (an account of which can be found in Henry 2012), Maggie's daughters gave Rosita a copy of the autobiography their mother had begun to write. It was something that Maggie had wanted Rosita to help her with before she died so, with the family's permission, Rosita began intermittently doing the field research necessary to complete the book, travelling to Papua New Guinea each year between 2009 and 2012, to stay at Maggie's house in Kunguma Village, on a mountain ridge above Hagen town.

11 In order to learn more about what life was like for Maggie, Rosita immersed herself as much as possible in the lives of Maggie's Penambi Wia kin, attending many compensation payments, funerals, brideprice and other types of ceremonial exchanges that preoccupied them. She often took a digital video camera with her, not with the view of making a film, but simply to record the proceedings for the participants and as part of her research documenting the unfolding of Maggie's life and her presence within an entangled web of kinship relations, even years after her death. The marriage of Maggie's daughter Nadia promised to be a significant event in that it would help to shed light on this complex web of relationships, particularly the long history of exchanges between Maggie's people, the Penambi Wia, and the Mogei Nambuga of the Hagen area.

\section{Father of the groom}

The groom's father, Phillip Num Maipson, bore the main responsibility for putting together the brideprice with the support of his Mogei Nambuga kinsmen, his exchange partners in other clans and his affinal kin. It was a considerable undertaking on his part to procure the large number of pigs and substantial amount of money that he wanted to give to the bride's kin to compensate them not only for Nadia, but also for the two children she had already borne. After much hard work, at the brideprice ceremony he was proudly able to present a very generous brideprice, one of the highest paid in the Western Highlands to date. 

anyone had ever done it before among Hagen people. Instead of presenting the whole brideprice to the bride's kin, the Penambi Wia, for redistribution, he made a point of giving a good part of the brideprice directly to the bride and groom (see videoinserts 1 and 2 where Phillip and his kinsman, John Pamunda, comment on the unique way in which the brideprice was presented).

In terms of understanding the importance of this marriage to the parties involved, it is particularly constructive to listen to the speeches that Phillip and his kinsmen gave during the brideprice exchange, where the history of relations between the Penambi Wia and the Mogei Nambuga were described, including not only past marriages that had contributed to building alliance relations between the two clans, but also a more distant history of tribal conflict in the 1920s during which the bride's great grandmother (Maggie's grandmother) had been killed.

\section{Video excerpt from An Extraordinary Wedding}

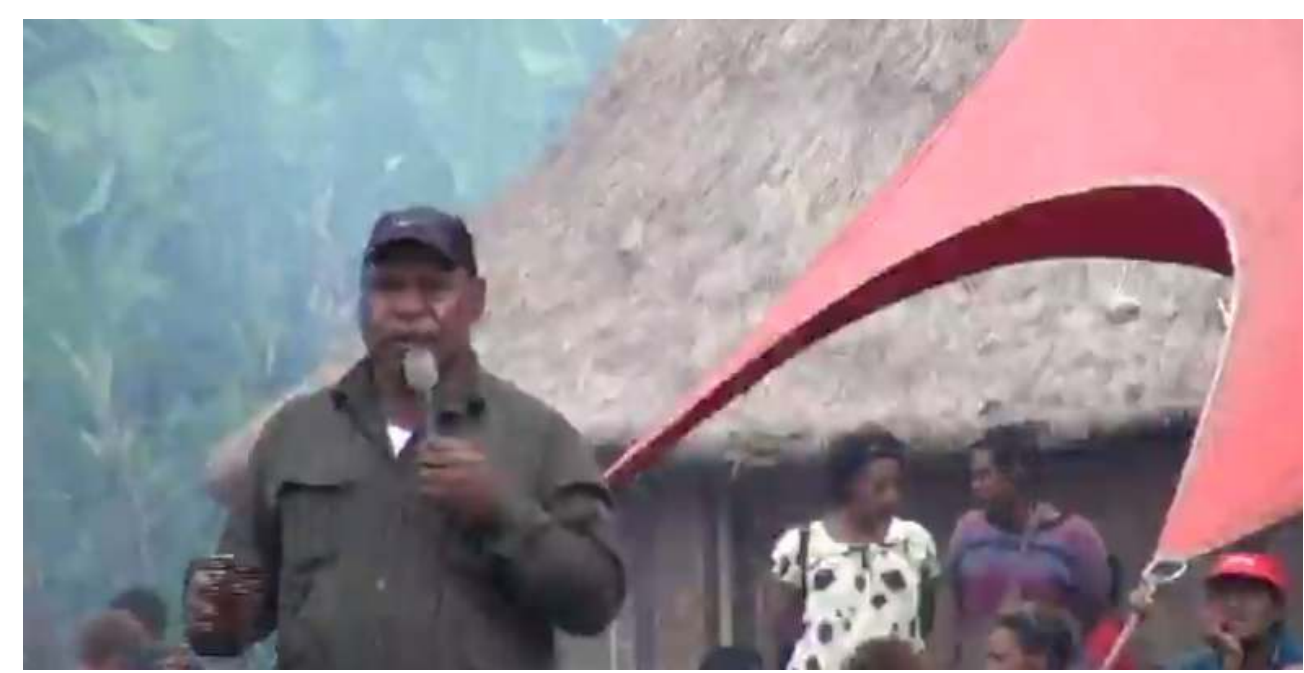

Phillip Num Maipson, father of the groom, and John Kawa, the bride's mother's brother, giving speeches at the brideprice exchange, Palimp Village, December. https://vimeo.com/197332741 password: wedding

A film by Rosita Henry and Daniela Vávrová

\section{Sisters of the bride}

During the years of research for Maggie's book, Rosita became especially close to Maggie's eldest daughter, Bernadine, who facilitated the project and hosted Rosita during her many visits to Kunguma Village. Thus, Bernadine and her husband Kanawi invited Rosita to stay at their house for the few weeks during which the brideprice transactions would take place. Bernadine, as the oldest of Maggie's children, took a strong lead in the arrangements for the marriage, assisted by her sister Olivia, brother Maki and the bride herself. First they had to organize with their Penambi kin the initiatory gift of cooked pigs and vegetable food that the bride's kin group is traditionally expected to carry to the place of the groom and present to his kin a week or so before the brideprice proper is to take place. Then, without knowing exactly how, what, or how much would be presented in brideprice, they had to carefully plan how it would be redistributed amongst their kin 
and friends once it was given. According to custom the redistribution has to take place in public immediately after the gift is given on the ceremonial ground of the groom's clan.

Since their mother, Maggie, had passed away and could not be present, the bride's older sisters, Bernadine and Olivia, were expected to accept the biggest pig ('mother's pig') and other goods and money that are traditionally presented to the mother of the bride.

The Bride's Sisters

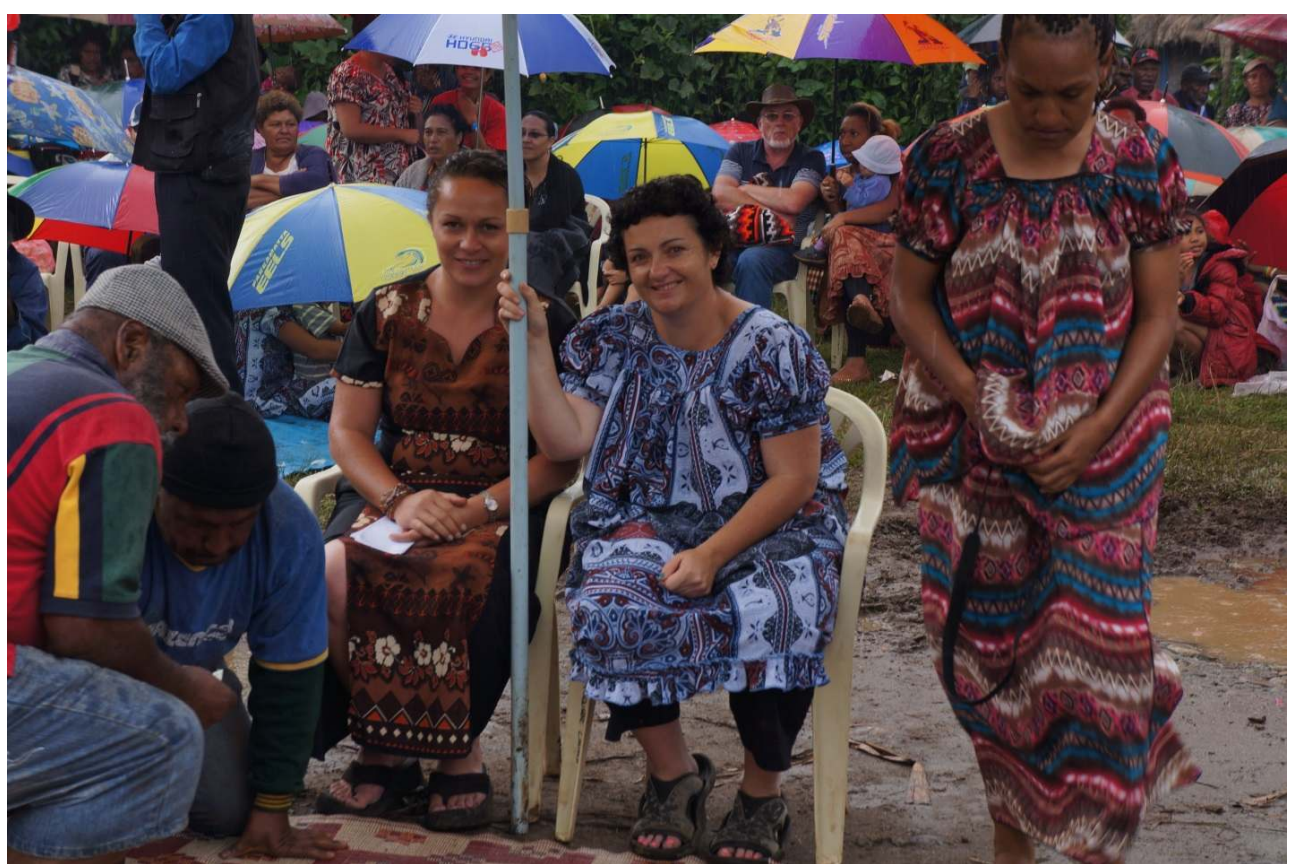

The bride's sisters being presented with gifts, seated from left to right, Olivia and Bernadine, with the bride, Nadia, standing, 29 December 2012.

PHOTO BY KANAWI DANOMIRA

Later, during the week after the brideprice, the sisters had to mobilise their kin to help procure new pigs of equivalent size to the ones that had been given. Customarily, half the number of pigs, vegetable and other goods and money that the bride's group receives from the groom's group are expected to be returned at a ceremony called the bekim (Tok Pisin meaning 'return'). It is important that the same pigs are not returned, so new pigs of the same size have to be found. On top of all of this planning and work, the sisters had to organise the marriage ceremony that was to be performed by the Catholic priest in conjunction with the bekim.

As witness to all the plans and preparations, Rosita sought and was given permission to film the full series of events that comprised the marriage, not only for her research towards Maggie's book, but also in order to make a 'wedding video' for the bride and groom.

\section{Filming the events}

19 Equipped with a light-weight digital camera and a tripod, Rosita attended and filmed not only the brideprice, the bekim, and the marriage ceremony performed by the Catholic 
priest, but also the thoughts and reflections of family members and friends before, during and after the events.

Rosita initially had no intention of making a film for an outside audience. She was the sole filmmaker and had no sound recording assistance. Moreover, she had training in neither filmmaking nor sound recording, and little experience with the newly purchased digital camera she had brought with her.

Filmmaker

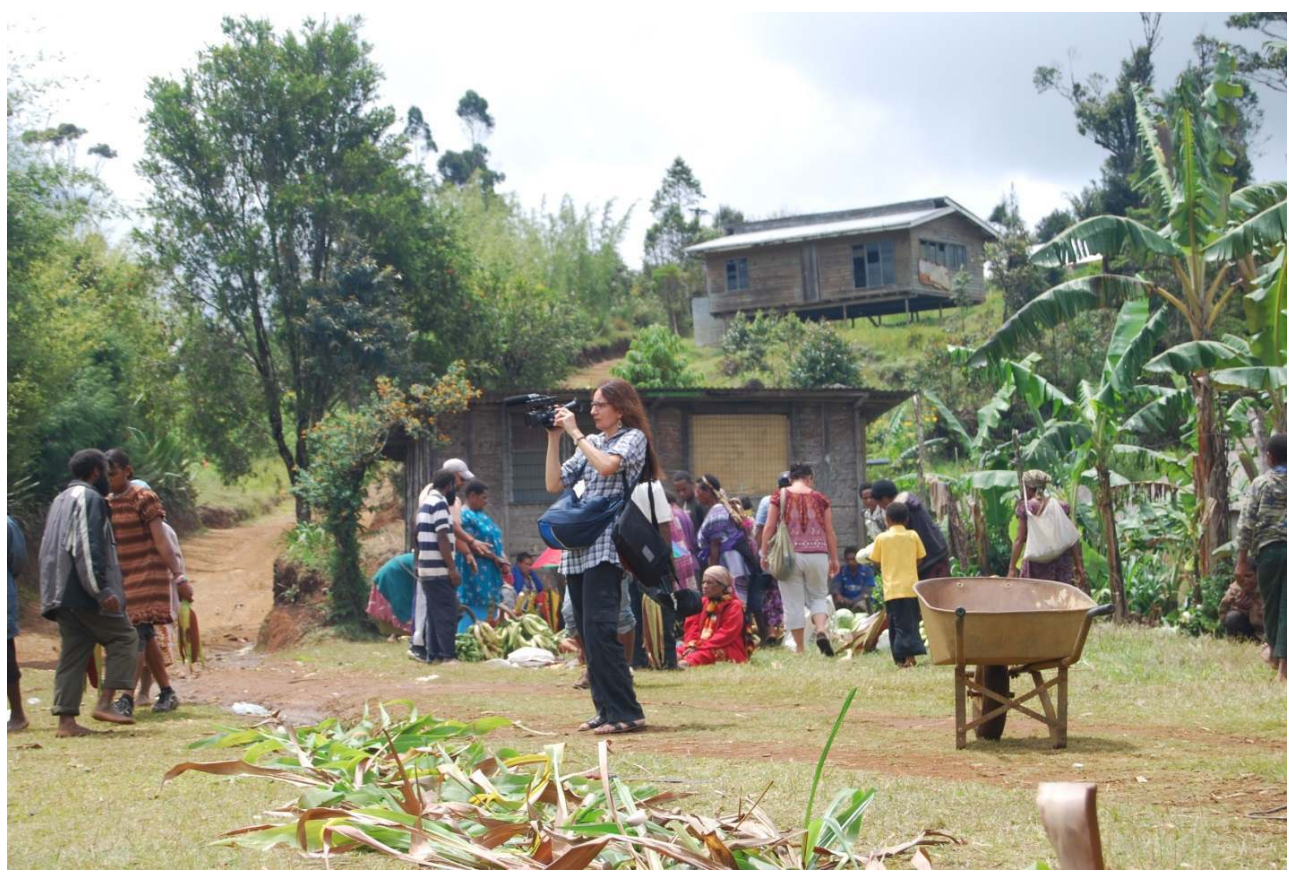

Rosita Henry filming preparations for the brideprice bekim in Kunguma Village, Western Highlands, PNG, 4 January 2013.

PHOTO BY KANAWI DANOMIRA

These limitations are evident in some of the footage. Initially Rosita did not use the tripod but held the camera in her hand and moved with the flow of the crowd as it entered the ceremonial grounds. However, knowing that public oratory is highly valued and politically significant in the Highlands of Papua New Guinea, after the speeches began, she decided to set up the tripod so she could focus the camera steadily on the speakers. As she was only using the simple directional microphone on the camera itself, Rosita did not dare to move the camera and tripod for fear of missing a significant part of the speeches. Unfortunately, this also meant that she was unable to use a diversity of camera angles. Much footage consists of hours of speeches, of great fascination to the participants and of research value to anthropologists and linguists in terms of the texts and meaning of what was said, but not necessarily aesthetically pleasing from a filmic perspective. The directional microphone captured the speeches quite well, apart from those by a couple of more softly spoken speechmakers.

21 As Errington and Gewertz (1987: 368) note, 'the anthropologist as memorializer' faces a particular dilemma. It is the anthropologist's (and filmmaker's) 'power to inscribe and thus memorialize - to render tangible and substantial individual lives - that makes him or her especially subject to coercion by claims of reciprocity to record not a dialogue with a plurality of voices, but a monologue in which an individual or a faction for political 
advantage presents one view as authoritative.' Thus, while tempted to scan the crowd and film the faces and responses of the listeners and the 'plurality of voices' in the crowd, Rosita focused her camera on the main speakers, those who were managing and controlling the proceedings.

Additionally, out of respect for the participants and concern not to impose herself too much, Rosita stood back and tended to film from a distance, only using the zoom function sparingly and taking few close-up shots. The long shots provide rich material on the crowd of participants in attendance at the event, and some of their responses and reactions to the speeches, but do not capture well the facial expressions of the orators. In the context of public oratory in PNG, which is often full of metaphors and hidden meanings, it is particularly important to see a speaker's face and bodily gestures, not just hear the voice, in order to fully understand what is being said.

It was only during the filming itself that Rosita became aware that the participants were constructing a certain narrative through their speeches and activities that would be fascinating to an outside audience. Again and again, participants claimed that this particular brideprice was different, that it was 'extraordinary'. Thus, Rosita began to film more strategically, adopting an anthropological lens and asking for clarification from behind the camera about how and why this brideprice was different from past brideprices in the Western Highlands (Merlan and Rumsey 1991; Strathern, A. 1972; Strathern, M. 1972, 1988; Strathern and Stewart, 1998). In other words, while she initially began to author the film only minimally through where she placed the camera and via her decisions about when to turn the camera on and off, she ended up authoring it much more consciously and with more direction, through her decision to ask questions and record participant responses. Altogether, Rosita filmed five hours of footage over two separate days, including interviews with participants before and after the main public events.

\section{Video excerpt from An Extraordinary Wedding}

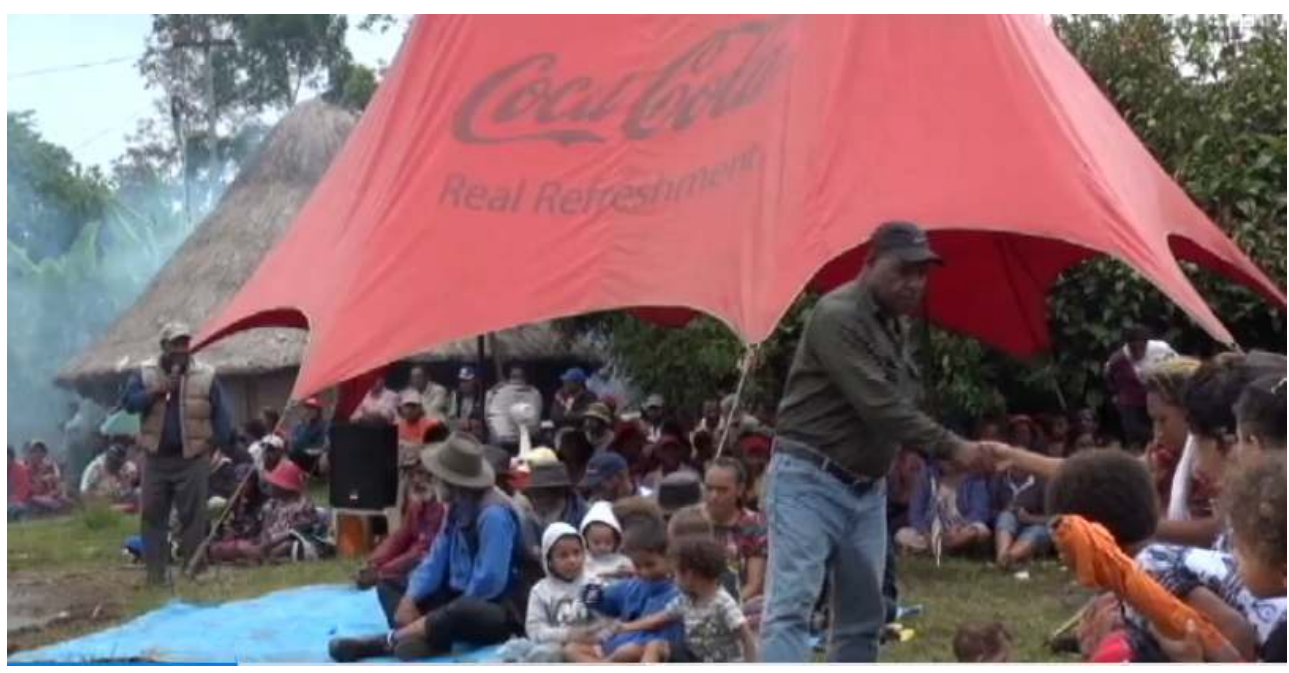

John Pamunda, member of the groom's clan, the Mogei Nambuga at the brideprice exchange, December 2012. https://vimeo.com/197332903 password: wedding

A film by Rosita Henry and Daniela Vávrová

While playing back the hours of footage to members of the family through the camera, when they gathered to debrief after the events, Rosita asked for permission to not only 
make the wedding video for the bride and groom, but also to edit the footage so as to make an ethnographic film. Maggie's children readily agreed, as did their Penambi Wia kinsman, Thomas Las, Maggie's younger brother, who is well acquainted with the trilogy by Bob Connolly and Robin Anderson. After all, it had been Maggie who had facilitated the filming of First Contact (1983). Some years later, in June 1990, during the shooting of their award-winning film Black Harvest (1992), the filmmakers sought refuge with Maggie at her village tourist lodge, Haus Poroman, after their house was destroyed during the tribal fighting in the Nebilyer Valley and the situation became dangerous for them at Kilima Plantation (Connolly 2005). In fact, her association with the filmmakers inspired Maggie to become a filmmaker herself. She took the opportunity to attend a videomaking workshop in PNG in 1984, Skul Bilong Wokim Piksa with Séverin Blanchet of Ateliers Varan, the cinéma vérité school founded by Jean Rouch in Paris, and in 1986 she travelled to Paris for a more advanced workshop in $16 \mathrm{~mm}$ with teams from Papua-New Guinea, Senegal, Brazil and Italy. During this workshop she made a film with two other Papua New Guineans (Kumain Nunguya Kolain and Lahui Vagi Geita) about French astronomers and their concept of the Universe entitled Raiders of the Planet Mars (Les aventuriers de la planète Mars) (See http://www.film-documentaire.fr/4DACTION/w_fiche_film/44947_1). Kumain Nunguya Kolain's film Sinmia: Haus Bilas Bilong Manmeri Bilong Baruya (1989) was one of the first PNG productions made by a PNG filmmaker in his own village. It is a Baruya perspective on the male initiation ritual.

For some years after her return to Papua New Guinea, Maggie worked as a filmmaker for the national PNG television channel EMTV ('emteevee'). Among the films that Maggie made during her filmmaking career for EMTV was a documentary entitled Bride Price in Hanuabada (1990) that explored the inflation of brideprice in this urban village in Port Moresby. Harnessing the support of her clan people, Maggie also established her own freelance filmmaking company in Mt Hagen, Tilkil Kuan Productions Pty Ltd. She wrote and directed her own video drama, Stolen Moments (1989), which was billed as 'a story of love and intrigue in contemporary Mt Hagen'. It was co-produced and co-edited by anthropologist Nancy Sullivan. According to Sullivan (2003: 379), '[o]nly two members of the cast were hired and the rest, like the crew, were associates and kin of Maggie's'. Thus, her kin are relatively well versed in how stories can be told, or messages conveyed, through film. 


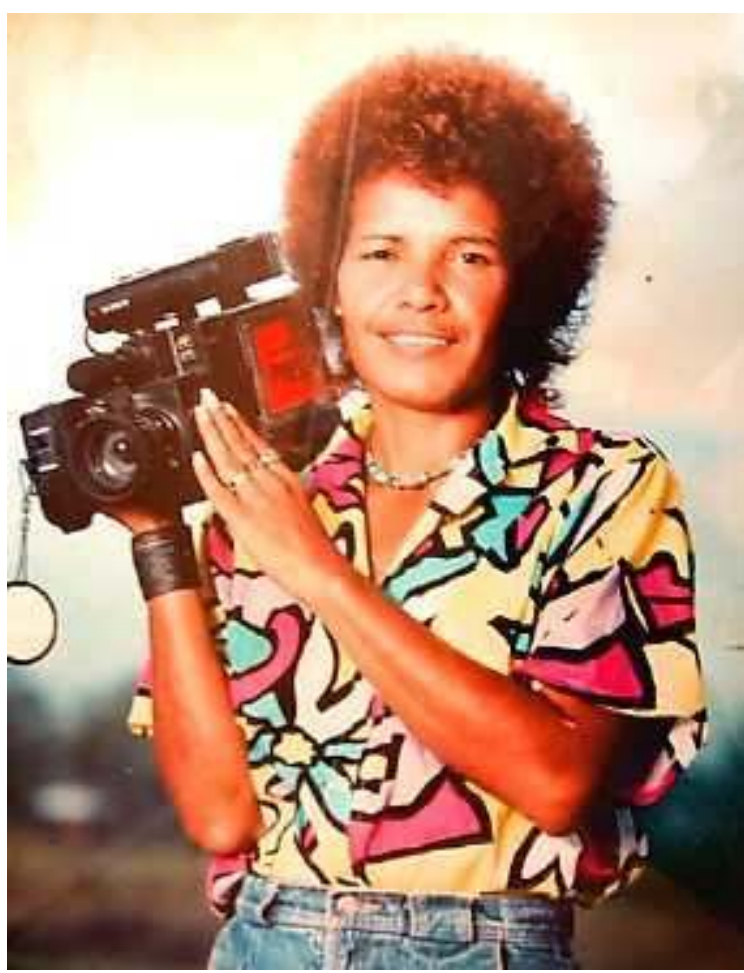

Maggie Wilson, filming for MTV

PHOTO FROM THE WILSON FAMILY ALBUM

Having watched the trilogy by Bob Connolly and Robin Anderson again and again in the tourist lodge that Maggie built in their village, her kin are also well aware of how narratives are able to escape their local origins to travel far and wide across time and place and how long after a film is made and released, 'stories are created by viewers around the film, stories of and from viewing experiences' (Mermin 1997: 40).

Thus, what began as an observational exercise to create a mere visual document aimed at providing an objective record of the events developed into something different as the filmmaker became aware of the narrative that the participants were themselves composing. As Henley (n.d.) notes: 'Although it might faithfully record what is in front of it, the camera clearly cannot determine the significance of what it records'. As anthropologists, our understanding of the significance of what was recorded, and the value of making the film for a wider audience of scholars, is informed by a substantial literature concerning transformations in brideprice exchanges in PNG (eg. Josephides 1999; Macintyre 2011; Stewart and Strathern 1998, 2002; Strathern and Stewart 2000; Sykes 2014; Zimmer-Tamakoshi 1997) as well as by other ethnographic films (such as Bridewealth For A Goddess by Chris Owen and The Institute of Papua New Guinean Studies 2000). Yet, to understand the importance of the event to the participants and why they presented the brideprice as 'extraordinary' required paying attention to the moment and the narrative that the participants were themselves constructing in the context of their very participation in the event.

It takes perceptive insight on the part of an ethnographer and filmmaker to recognize the narrative practices of the participants in the activities being filmed and then to work with the unfolding narrative. In other words the actors or participants, as authors of their 
own lives, actually narratively direct the filming, so that authorship of the film is already a shared, dialogic process from the moment the camera is turned on. Yet, participant contribution to authorship of a film often halts once filming stops and the editing process begins, unless conscious effort is made to involve the actors in editorial decision making. As she had little experience in film editing, Rosita invited ethnographic filmmaker Daniela Vávrová, based at the Anthropological Laboratory for Audiovisual Research (ALTAR), James Cook University, to join her on the project as the film editor. Rosita had in mind an ethnographic film of less than 50 minutes, which would be suitable for screening for teaching purposes.

\title{
Editing the footage - early stages
}

\begin{abstract}
'Brideprice is not buying a woman. Brideprice brings two tribes together and it seals the marriage. In the fifties, in the forties, in the sixties, when a man and woman got married and brideprice was paid, the marriage was sealed and they lived together until they got older and they brought up kids and they got older and they died and they went to the same cemetery and it worked very well ... Nowadays, people are going to school, they are getting educated. Boys are having girlfriends, girls are having boyfriends, and they say, 'I love you, I love you', and love also seals a marriage.' (Thomas Las, 2012, in An Extraordinary Wedding)
\end{abstract}

With these words Daniela chose to start the narration in An Extraordinary Wedding. Daniela knew very little about the background of the wedding prior to receiving the footage for editing. She was, however, excited about it, having had her own experiences doing research in Papua New Guinea (PNG). She was familiar with Tok Pisin and the sociocultural constraints pertaining to PNG communities (Vávrová 2014). Moreover, she was eager to learn about the changes in brideprice exchange. Daniela was given the footage of several series of events spread over a period of time and in two different locations, namely, Palimb and Kunguma villages. In addition to this footage, Rosita provided a long conversation with Thomas Las, the bride's mother's brother. After listening to this, Daniela decided to use Thomas reflections as a means of anchoring the story and elucidating the changes in customary practices of gift exchange and marriage.

The first storyline took the form of a simple chronology of events. Daniela cut out most of the passages that were out of focus or too shaky, but decided to keep some of these because of their chronological importance and their apparent narrative significance. She looked for editing within the shots and used minimum transitions, using Thomas' explanations as a bridge between the sequences. The next step was watching the first cut with Rosita to work out ways to reduce the length, which was over an hour and a half long. Sequences in local languages were kept as these still needed to be translated. Soon afterwards, Rosita returned to PNG and showed the rough cut to bride's family, including Thomas Las. This was the first opportunity for feedback on the editing of the film (see part on 'Editing as participatory practice').

Rosita's recordings had two angles of view: one of a family friend and the other one of a researcher documenting what was happening. As an external editor Daniela became the second viewer after the filmmaker herself. It is the editor who slices the sequences together creating new meaning. An external editor does not know more than she sees and hears from provided footage. Jean Rouch argued that external editors are needed as they bring an objective perspective into the dialogue between subjective filmmakers and protagonists (in Feld 2003: 40). Usually, authors of ethnographic films insist on 'the 
priority of the given' or, as Dai Vaughan writes, 'that meaning should be generated directly from the organization of the visual and auditory material, rather than this material being subordinated to something prior or extrinsic - typically, a pre-scripted schema or a dominant verbal narration' (1999: xv). In editing An Extraordinary Wedding, Daniela tried to keep a balance between this insistence and a more dynamic montage with additional recordings. She was aware of the importance of the two sites of the brideprice (the villages of the groom and the bride) and kept a key speaker from each site and side dominant in the two parts of the film.

After showing the rough cut to an ethnographic filmmaker who was not familiar with the cultural context of brideprice exchange in the Highlands of PNG, it became clear that there was a need to clarify to an outsider the identities and roles of the various characters. Thus, we decided to create an introduction to outline the kinship relationships in the film. We also thought that it would be helpful to add some explanatory commentary by the main female character, the bride's oldest sister Bernadine. We were concerned about how to best convey to an outside audience the complex interrelationships among the participants in this PNG context. For the sake of the insider audience, however, we had to avoid oversimplifying and cutting out too much. While an outsider audience might find the speeches long and tedious, these were in fact the most interesting and engaging aspect of the film for insiders. The dilemma we faced was that in order to shorten the film and make it engaging for an outside audience, we had to cut some of the speeches but if we did so, people could feel insulted or excluded.

There were several scenes that were recorded out of focus, overexposed, or the voices were too low to hear. These are common problems when recording in the field alone. One has to pay attention not only to the technical issues, but also listen to the people in conversation and even maybe take part in it. One often forgets to check the camera settings when focused on listening and participating in discussion. Yet, these difficulties can also become an advantage in editing. We were forced to find a way to disclose things in a balanced way that could be understood by an outsider audience but that would still ring true to an insider. Thus, we experimented with stills and voice over in order to save scenes that were crucial to the narrative but that were out of focus or that had poor sound. Ultimately, the editor is directed by the viewer. For An Extraordinary Wedding, the audience that we had in mind when we began editing included foremost the protagonists themselves, their children and grandchildren. At the same time, we wanted to address anthropologists, who are interested in social and cultural transformation, especially issues associated with contemporary brideprice exchanges in PNG. We envisioned a film that would have educational value and could be used for teaching as this was the main expectation of the key participants, the bride and groom and their kin, in opening their lives to public scrutiny. For them 'a wider audience' means other people from Hagen, the Western Highlands and Papua New Guinea in general, as well as a global audience of students interested in learning about the social and cultural complexities of contemporary life in PNG.

\section{Editing as participatory practice}

Daniela created the second cut based on feedback Rosita had received from key participants in the film during her visit to Kunguma Village. 
Participatory Editing

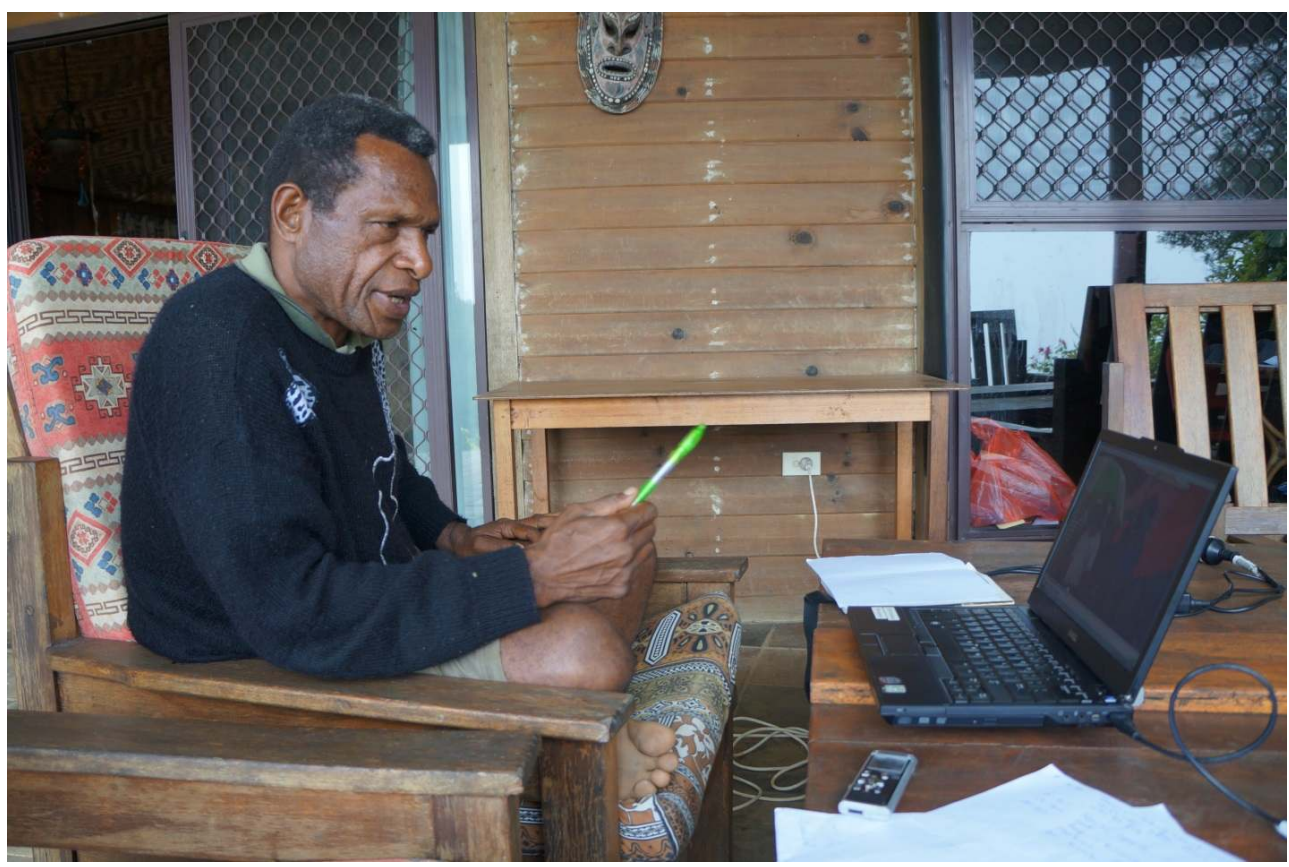

Thomas Las watching and commenting on the first cut of An Extraordinary Wedding

PHOTO BY ROSITA HENRY

Daniela edited the cut accordingly, but several of the events that the participants requested to be included were out of focus. This complicated the situation and meant that a compromise had to be found. The participants also wanted to shorten or cut some sequences, as they did not think these family tensions should be publicly aired. In particular, they wanted certain speeches and conversations to be cut from the film in case they caused embarrassment or even conflict among family members. While the events had occurred in public, repetition of them in the film might rekindle tensions that would otherwise lie dormant. Most of these sequences were in the local language (tok ples) which Daniela did not understand. She had included the shots for the sake of chronology and because they were technically well shot, were aesthetically pleasing to her and had an expressive mood. These considerations, however, were not as important to the participants as what was actually said. Thus, several sequences that Daniela initially liked and had linked together were edited.

There were also other responses from participants in the events filmed that made Daniela think differently about the next stage of editing. In the first cut, to open the film, she included a compilation of several scenes that were out of chronological order. She did not specifically intend to disturb the chronology of events, but wanted to introduce certain characters early in order to draw the viewer into the story and set the scene for what was to come. However, after seeing the rough cut, a participant asked for one of these scenes to be removed. This was a scene in which the bride's kinsman was counting pigs. The participants advised that the original sequence of events had to be maintained in this case as it would be deemed very impolite to start counting gifts before they were actually presented. A dynamic and discontinuous style of editing and juxtapositioning of shots was inappropriate in this case. 

editing studio and gave her further suggestions. Daniela is currently further editing the film. The participatory approach to editing that we have attempted for An Extraordinary Wedding has led us to reflect critically upon the authorial strategies we have adopted to create this ethnographic film.

\section{Authorial strategies - Ethical and aesthetical}

Ethnographic filmmaking raises ethical issues with regard to the relation between our own voices as filmmakers and anthropologists and the other voices constructing the narrative. MacDougall argues that 'it is only through the author's agency that we are allowed to hear other voices, by a process of "transmission"' (1998: 156). There have been attempts to include a multiplicity of voices and plural authorship in so called 'polyphonic' films (Eraso 2006: 1). But there is also a danger that such films create contradictory arguments leading to confusion among viewers.

Eraso (2006: 11) writes that in the expositional style of ethnographic films 'there is an argument around which the film is constructed and through which it evolves, and the images and narratives are chosen to support this'. However, in An Extraordinary Wedding it became evident to us early in the piece that it was mostly the participants themselves constructing the narrative. This is not to say that we were not aware of our own authorial agency, but that it was already tempered by what the participants were saying and doing.

According to MacDougall (1998: 158):

"Films are shaped as much by the structures into which they are placed as by their avowed form and intention. The making of some films is thus part of a social process larger than the film itself."

42 An Extraordinary Wedding is this kind of film. We felt that it was imperative to include some scenes in the film because of their importance for understanding that brideprice is not as much about the relationship between the bride and the groom as about a continuing social process that includes historical ties of alliance and enmity between their clans. The past relationship between the clans of the bride and the groom was raised repeatedly during the speeches. Even events that had occurred as far back as the 1920s were mentioned. At one point, special note was made of the death of the bride's greatgrandmother during a tribal war in which the groom's and the bride's clans had been on opposite sides of the conflict. The bride's mother, Maggie Wilson, mentions this event in her autobiography (Wilson and Henry, in prep.):

"My father Kuan was the eldest surviving child of our lineage in the Penambi Wia sub-clan and he was about 13 at the time; he had four younger brothers, Tugl, Wai, Penapel and Kut who was the youngest, then only two or three years old. Their father, my grandfather Megl, had died of natural causes two crop cycles before this war but their mother, my grandmother, was killed during the war."

43 As part of Nadia's brideprice exchange, the groom's side, the Mogei Nambuga, presented the Penambi Wia with some pigs in compensation for the death of Maggie's grandmother (father's mother) during this 1920s war, which is also mentioned in Connolly (2005: 226). We felt it was important to highlight this exchange in the film, knowing, as anthropologists, that a history of past relations between groups is crucial to a full understanding of the meaning of the speeches and actions of participants in any exchange ceremony in the Western Highlands. Yet, the complexity of such relations is not 
as readily conveyed through a visual mode of representation as through a written ethnographic text (Hastrup 1992).

According to Herzfeld (1997: 6) it was 'the encounter' between his anthropological interests and the writings of Andreas Nenedakis, whose biography he wrote, that helped him to understand how Andreas negotiated 'the engagement of his cultural background, his sense of tradition and value, with the encompassing enormities of his times'. Similarly, in the making of An Extraordinary Wedding, the encounter between our interests as anthropologists and the practices and performances of the people filmed helped us to understand how Western Highlanders negotiate concepts of tradition and modernity and different notions of value in these times of rapid social change in PNG. We have wrestled with the problem of effectively conveying the social transformations and rise of new inequalities in PNG that are expressed in brideprice exchanges. Do the authorial strategies we have employed for the film have the capacity to reveal complex intertwined histories and emerging inequalities of race, gender, and class? It seems possible to only partially address these issues via editorial techniques and the inclusion of particular speech events. Yet, because of the agency of the viewer, an ethnographic film just like a documentary 'always exceeds its maker's prescriptions' (Vaughan 1999: 82).

As Vaughan (1999: 83) writes, '[j]ust as the ethics of filmmakers are experienced as aesthetics by the viewer, so the anthropologist's objectivity translates into ambiguity: and the "real-life" density commonly attributed by viewers to such film is our experience of active engagement in the generation of meaning'. An Extraordinary Wedding is a collective creation of meaning by many agents - participants, filmmaker, editor, and the various viewers (potential, virtual and actual). Today the people with whom anthropologists conduct research often readily embrace the potential of film to generate their own meanings and achieve their own narrative ends. For example, Yolngu people in Australia, according to Jennifer Deger (2007), have sought to produce their own desired effects in film and 'to reach an audience dispersed over both time and space, and beyond restrictions of clan, age, or gender' (Deger 2007: 108-109; see also De Largy Healy 2013).

Anthropologists, filmmakers, editors, viewers and the people whose lives are featured in ethnographic films are all engaged in 'narrative practices' (Gubrium and Holstein 2008).Yet, like all practices, narrative practices are subject to power relations. As Barbara Glowczewski reminds us, on the basis of her experience with Warlpiri people in Australia, '[r]esearch implies constant negotiations, as contexts change with time, as do cultural priorities' (2014: 159). Glowczewski argues for taking into account our subjects' perceptions, 'that is, the way they express their visions, memories, and history, as well as assemblages that include other agents, and all living systems intertwined with environment and technology' (2014: 147). The interpretive power of the anthropologist is always constrained by the historical context and the interests and understandings of the people whose lives or lifeworlds are being explored. This productive tension is not specific to visual anthropology. It lies at the core of ethnography, indeed of all social inquiry. Nevertheless, the narrative practices of the ethnographic filmmaker and editor usually remain dominant in the creation of the final product, even where participatory filmmaking is attempted as a means 'to add integrity to the ethnographic documentary film' (Mathew 2014: 20). 


\section{Conclusion}

Crane (1991: 295) writes that authors 'determine the order in which they unfold their arguments, and this power of presentation is enormous'. As filmmakers we have the power to edit, to select and exclude, to highlight and comment on, and to circumvent the linear path in the way events temporally unfold. But the perceptiveness and discernment of the viewer, both insider and outsider, limits our power. As filmmakers we are constrained by what we think the viewer will be able to grasp of the meaning we are trying to convey. In this sense our visual narrative is 'composed' or 'crafted' rather than 'created' or 'produced' (Crane 1991: 293). We have tried to convey that, for both the participants and the anthropologists, the wedding is extraordinary not only because a large part of the brideprice was given directly to the bride and groom as a couple, which is not customarily how brideprice is distributed, but also because of the status of the particular families involved. The bride's mother, Maggie Wilson, was a highly respected big woman in the Western Highlands and also a Leahy, daughter of one of the first white men to settle permanently in the Hagen area and this fact is emphasised in some of the speeches filmed. However, there are also other things, apparently taken-for-granted by the participant insiders, which might appear extraordinary to an outside viewer. For example, introduced animals such as goats and sheep supplement the rows of pigs that are customarily given, indicating the presence of Seventh Day Adventist converts among the participants. Other iconic signifiers of modernity and social transformation, including a coca cola marquee, a portable electric fan and a microphone, appear in the film. Such symbols of wealth are not present at all brideprice exchanges in the Western Highlands, but are relatively common among well-to-do Papua New Guineans living in, or in close proximity to, urban centres.

In editing An Extraordinary Wedding, we moved from first imagining that we were going to play only a very minor part in the authorship of what initially was to be merely an 'observational' film, to recognizing and facing up to the weight of our own narrative practices and authorial contributions as anthropologists, filmmakers and editors. By engaging with the characters whose lives are portrayed in the film in a process of participatory editing, we have tried to ethically convey the intricacies of the social relationships at stake for them while, at the same time, leaving some space for aesthetic expression and experiential freedom in viewing this film. As a result we hope that the final cut will allow for many different analyses and interpretations concerning the extraordinariness of this wedding.

\section{BIBLIOGRAPHY}

\section{Books and Articles}

Clifford, James and George E. Marcus, eds. 1986. Writing Culture: The Poetics and Politics of Ethnography. Berkeley: University of California Press. 
Connolly, Bob. 2005. Making 'Black Harvest': Warfare, Film-making and Living Dangerously in the Highlands of Papua New Guinea. Sydney: ABC Books.

Connolly, Bob and Robin Anderson. 1987. First Contact. New York: Viking Penguin Inc. Crane, Gregory. 1991. Composing Culture: The Authority of an Electronic Text. Current Anthropology 32(3): 293-311.

Deger, Jennifer. 2007. Seeing the Invisible: Yolngu Video as Revelatory Ritual. Visual Anthropology 20(2-3): 103-121.

De Largy Healy, Jessica. 2013. Yolngu Zorba meets Superman: Australian Aboriginal people, mediated publicness and the culture of sharing on the Internet. Anthrovision 1(1), http:// anthrovision.revues.org/362. (accessed 11 June, 2016).

Eraso, Laura. 2006. Reflecting Upon Interculturality in Ethnographic Filmmaking. Forum Qualitative Sozialforschung / Forum: Qualitative Social Research 7(3): 1-11, http://www.qualitativeresearch.net/index.php/fqs/article/view/137/300. (accessed 10 April, 2016).

Errington, Frederick and Deborah Gewertz. 1987. Of Unfinished Dialogues and Paper Pigs. American Ethnologist 14(2): 367-76.

Feld, Steven. 2003, ed. Ciné Ethnography. Jean Rouch. Minneapolis: University of Minnesota Press. Geertz, Clifford. 1988. Works and Lives: The Anthropologist as Author. Stanford: Stanford University Press.

Glowczewski, Barbara. 2014. Beyond the Frames of Film and Aboriginal Fieldwork. In Experimental Film and Anthropology. Caterina Pasqualino and Arnd Schneider, eds. Pp. 147-164. London: Bloomsbury Academic.

Gubrium, Jaber F. and James A. Holstein. 2008. Narrative Ethnography. In Handbook of Emergent Methods. Sharlene Nagy Hesse-Biber and Patricia Leavy, eds. Pp. 241-64. New York: The Guilford Press.

Hastrup, Kirsten. 1992. Anthropological Visions: Some Notes on Visual and Textual Authority. In Film as Ethnography. Peter Ian Crawford and David Turton, eds. Pp. 8-25. Manchester: Manchester University Press.

Henley, Paul. n.d. Authorship in Western Ethnographic Film-making: A Selective History, https:// www.escholar.manchester.ac.uk/api/datastream?publicationPid=uk-ac-manscw:3b3669\&datastreamId=FULL-TEXT.PDF (accessed 4 March, 2015).

Henry, Rosita. 2012. Gifts of Grief: Performative Ethnography and the Revelatory Potential of Emotion. Qualitative Research 12(5): 528-39.

Herzfeld, Michael. 1997. Portrait of a Greek Imagination: An Ethnographic Biography of Andreas Nenedakis. Chicago: The University of Chicago Press.

Josephides, Lisette. 1999. Disengagement and Desire: The Tactics of Everyday Life. American Ethnologist 26(1): 139-159.

MacDougall, David. 1998. Transcultural Cinema. Princeton: Princeton University Press.

Macintyre, Martha. 2011. Money Changes Everything: Papua New Guinean Women in the Modern Economy. In Managing Modernity in the Western Pacific. Mary Patterson and Martha Macintyre, eds. Pp 90-120. St Lucia: University of Queensland Press.

Mathew, Wesley. 2014. Reality in Ethnographic Film: Documentary vs. Docudrama. Visual Anthropology 27(1-2): 17-24. 
Merlan, Francesca and Alan Rumsey. 1991. Ku Waru: Language and Segmentary Politics in the Western Nebilyer Valley, Papua New Guinea. Cambridge: Cambridge University Press.

Mermin, Elizabeth. 1997. Being Where? Experiencing Narratives of Ethnographic Film. Visual Anthropology Review 13(1): 40-51.

Ruby, Jay. 1992. Speaking For, Speaking About, Speaking With, or Speaking Alongside: An Anthropological and Documentary Dilemma. Journal of Film and Video 44(1/2): 42-66.

Stewart, Pamela J. and Andrew J. Strathern. 1998. Money, Politics, and Persons in Papua New Guinea. Social Analysis: The International Journal of Social and Cultural Practice 42(2): 132-149.

Stewart, Pamela J. and Andrew J. Strathern. 2002. Transformations of Monetary Symbols: in the Highlands of Papua New Guinea. L'Homme 162(avril/juin): 137-156.

Strathern, J. Andrew. 1972. One Father, One Blood: Descent and Group Structure among the Melpa People . Canberra: ANU Press.

Strathern, J. Andrew and Pamela J. Stewart. 1998. Seeking Personhood: Anthropological Accounts and Local Concepts in Mount Hagen, Papua New Guinea. Oceania 68(3): 170-188.

Strathern, J. Andrew and Pamela J. Stewart. 2000. Creating Difference: A Contemporary Affiliation Drama in the Highlands of New Guinea. The Journal of the Royal Anthropological Institute 6(1): 1-15.

Strathern, Marilyn. 1972. Women in Between: Female Roles in a Male World, Mt Hagen, New Guinea. London \& New York: Seminar Press.

Strathern, Marilyn. 1988. The Gender of the Gift: Problems with Women and Problems with Society in Melanesia. Berkeley and Los Angeles: University of California Press.

Sullivan, Nancy. 2003. Television and Video Production in Papua New Guinea: How Media Become the Message. In Television: Critical Concepts in Media and Cultural Studies, vol. 1, Part 3. Toby Miller, ed. Pp. 369-391. London and New York: Routledge.

Sykes, Karen. 2014. Mortgaging the Bridewealth: Problems with Brothers and Problems with Value. HAU: Journal of Ethnographic Theory 3(2): 97-117.

Vaughan, Dai. 1999. For Documentary: Twelve Essays. Berkeley: University of California Press.

Vávrová, Daniela. 2014. “Skin has Eyes and Ears”. Audio-visual Ethnography in a Sepik Society.' $\mathrm{PhD}$ thesis including film with the same title, James Cook University.

Zimmer-Tamakoshi, Laura. 1997. The Last Big Man: Development and Men's Discontents in the Papua New Guinea Highlands. Oceania 68(2) : 107-122.

Films

Connolly, Bob and Robin Anderson, dirs. 1983. First Contact. Bob Connolly and Robin Anderson (production). $53 \mathrm{~min}$.

Connolly, Bob and Robin Anderson, dirs. 1989. Joe Leahy's Neighbours. Bob Connolly and Robin Anderson (production). $90 \mathrm{~min}$.

Connolly, Bob and Robin Anderson, dirs. 1992. Black Harvest. Bob Connolly and Robin Anderson (production). $90 \mathrm{~min}$.

Nunguya, Kumain, Lahui Vagi Geita and Magdaline Wilson, dirs. 1987. Les Aventuriers de la planète Mars. Ateliers Varan (production). 25 min.

Nunguya Kolain, Kumain. 1989. Sinmia: Haus Bilas Bilong Manmeri Bilong Baruya. Skul Bilong Wokim Piksa and Atelier Varan (production). $47 \mathrm{~min}$. 
Owen, Chris, dir. 2000. Bridewealth For A Goddess. The Institute of Papua New Guinean Studies (production). $72 \mathrm{~min}$.

Wilson, Maggie, dir. 1989. Stolen Moments. Tilkil Kuan Productions Pty Ltd. 60 min.

Wilson, Maggie, dir. 1990. Bride Price in Hanuabada. EMTV (production).

\section{ABSTRACTS}

In attempting to create visual narratives, ethnographic filmmakers often face intractable dilemmas of choice, both ethical and aesthetical, in what to sacrifice from many hours of footage of complex socio-cultural practices and performances. How do we author a narrative that can be understood and appreciated by a broader audience without diminishing the integrity of the lifeworld of the characters? How do we convey the intricacies of the social relationships at stake while, at the same time, leaving some space for experiential freedom in viewing the film? These are some of the questions that we have grappled with in the making of An Extraordinary Wedding, a film about contemporary marriage and brideprice exchanges in the Western Highlands of Papua New Guinea. In this piece we reflect upon the ethics and aesthetics of the authorial strategies we have employed in this work-in-progress.

Dans leurs tentatives pour créer des récits visuels, les cinéastes ethnographes sont souvent confrontés à d'insolubles dilemmes tant éthiques qu'esthétiques quant au choix des séquences à sacrifier parmi les nombreuses heures d'images montrant les complexes pratiques et performances socio-culturelles. Comment créer un récit qui puisse être compris et apprécié par un large public sans pour autant diminuer l'intégrité du monde habité par les personnes représentées ? Comment transmettre les subtilités des relations sociales en jeu tout en laissant une certaine liberté au spectateur ? Ce sont là quelques-unes des questions auxquelles nous avons été confrontées lors de la réalisation d'« Un mariage extraordinaire », film sur le mariage contemporain et les échanges autour du « prix de la mariée » dans les Hautes-Terres occidentales de Papouasie Nouvelle-Guinée. Cet article discute les enjeux éthiques et esthétiques des stratégies d'auteurs que nous avons adoptées dans ce travail en cours de progression.

En sus tentativas para crear historias visuales, los cineastas etnógrafos deben confrontarse a menudo con insuperables dilemas de carácter ético y estético en relación a la elección de secuencias que hay que sacrificar entre las numerosas horas de imágenes que muestran complejas prácticas y performances socioculturales. ¿Cómo crear una narración que pueda ser comprendida por un público amplio sin disminuir la integridad del universo vital de los actores? Estas son algunas de las cuestiones a las que nos hemos tenido que enfrentar durante la realización de "Una boda extraordinaria", una película sobre las bodas contemporáneas y las discusiones en relación al "precio de la novia" en las tierras altas occidentales de Papúa NuevaGuinea. Este artículo discute las problemáticas éticas y estéticas de las estrategias que, como autores, hemos adoptado en este trabajo, todavía en fase de realización. 


\section{INDEX}

Keywords: Ethnographic film, visual anthropology, Papua New Guinea, Western Highlands, research ethics, brideprice

Mots-clés: Film ethnographique, anthropologie visuelle, Papouasie Nouvelle-Guinée, HautesTerres occidentales, éthique de la recherche, prix de la mariée

Palabras claves: Cine Etnográfico, Antropología Visual, Papúa Nueva-Guinea, Tierras Altas Occidentales, Ética de la investigación, Precio de la novia

\section{AUTHORS}

\section{ROSITA HENRY}

James Cook University, College of Arts, Society \& Education, Townville, Queensland, Australia Rosita.Henry@jcu.edu.au

\section{DANIELA VÁVROVÁ}

James Cook University, Anthropological Laboratory for Audiovisual Research, The Cairns Institute and College of Arts, Society \& Education, Cairns, Queensland, Australia

Daniela.Vavrova@jcu.edu.au 